\title{
HUBUNGAN ANTARA PENGETAHUAN TENTANG KEBUTUHAN GIZI DAN INDEKS MASSA TUBUH DENGAN KADAR HEMOGLOBIN PADA REMAJA PUTRI DI ASRAMA AKADEMI KEBIDANAN PANCA BHAKTI PONTIANAK KABUPATEN KUBURAYA TAHUN 2019
}

\author{
Denny Pebrianti ${ }^{1}$, Telly Katharina ${ }^{2}$, Antika Nurvidary ${ }^{3}$ \\ Akademi Kebidanan Panca Bhakti Pontianak \\ Email korespondensi: akbidpbpontianak@gmail.com
}

\begin{abstract}
Abstrak
Perubahan fisik karena pertumbuhan yang terjadi akan mempengaruhi status kesehatan dan gizinya. Ketidakseimbangan antara asupan kebutuhan atau kecukupan akan menimbulkan masalah gizi, baik itu berupa masalah gizi lebih maupun gizi kurang. Status gizi dapat ditentukan melalui pemeriksaan laboratorium maupun secara antropometri. Menurut Riskesdas tahun 2018 Proposi Berat Badan Lebih dan Obese pada dewasa $>18$ tahun sejumlah $21,8 \%$. status gizi mempunyai korelasi positif dengan konsentrasi hemoglobin. Penelitian ini bertujuan untuk mengetahui hubungan antara pengetahuan tentang kebutuhan gizi dan indeks massa tubuh dengan kadar hemoglobin pada remaja putri di asrama akademi kebidanan panca bhakti Pontianak kabupaten kuburaya tahun 2019. Desain penelitian ini menggunakan observasional analitik dengan pendekatan cross sectional dengan jumlah sampel 51 orang serta menggunakan instrument penelitian kuisioner dan lembar ceklist. Hasil penelitian menunjukkan bahwa sebagian dari responden yaitu 29 responden (57\%) memiliki pengetahuan yang baik tentang kebutuhan gizi pada remaja. Sebagian dari reponden yaitu 28 orang $(55 \%)$ memiliki status gizi yang ditunjukkan dengan Indeks Massa Tubuh normal. Sebagian besar dari reponden yaitu 33 orang $(65 \%)$ memiliki kadar hemoglobin $(\geq 12,0 \mathrm{~g} / \mathrm{dl})$ atau tidak anemia. Hasil uji statistik diperoleh nilai $\mathrm{X}$ hitung $(13,63)$ lebih besar dari X tabel $(3,841)$ maka disimpulkan bahwa ada hubungan antara pengetahuan tentang kebutuhan gizi remaja dengan kadar hemoglobin. Hasil uji statistik diperoleh nilai X hitung $(8,25)$ lebih besar dari X tabel $(3,841)$ maka disimpulkan bahwa ada hubungan antara Indeks Massa Tubuh (IMT) dengan kadar hemoglobin pada remaja putri di Asrama Akademi Kebidanan Panca Bhakti Pontianak Kabupaten Kubu Raya pada tahun 2019. Saran yang dapat peneliti sampaikan adalah penelitian ini dapat digunakan sebagai informasi dan referensi dalam menunjang proses belajar mengajar di Akademi Kebidanan Panca Bhakti Pontianak.
\end{abstract}

Kata kunci: Pengetahuan, Kebutuhan Gizi, Indeks Massa Tubuh, Kadar Hemoglobin, Remaja Putri

\section{Pendahuluan}

Masa remaja merupakan periode dari

pertumbuhan dan proses kematangan manusia, pada masa ini terjadi perubahan yang sangat unik dan berkelanjutan. Perubahan fisik karena pertumbuhan yang terjadi akan mempengaruhi status kesehatan dan gizinya. Ketidakseimbangan antara asupan kebutuhan atau kecukupan akan menimbulkan masalah gizi, baik itu berupa masalah gizi lebih maupun gizi kurang. Status gizi dapat ditentukan melalui pemeriksaan laboratorium maupun secara antropometri. Kekurangan kadar hemoglobin atau anemia ditentukan dengan pemeriksaan darah.

Menurut Riskesdas tahun 2018 Proposi

Berat Badan Lebih dan Obese pada dewasa $>18$ tahun, dari 2007-2018 yaitu pada prevalensi overwightpada tahun 2007 8,6\%, pada tahun 2013 11,5\% dan tahun 2018 $13,6 \%$. Sedangkan prevalensi remaja denga obese pada tahun 2007 10,5\%, pada tahun 2013 14,8\% dan tahun 2018 21,8\%. Profil Kesehatan Kabupaten Kubu Raya Tahun 2018

\footnotetext{
${ }^{1}$ Dosen Akademi Kebidanan Panca Bhakti Pontianak

${ }^{2}$ Dosen Akademi Kebidanan Panca Bhakti Pontianak

${ }^{3}$ Mahasiswa Akademi Kebidanan Panca Bhakti Pontianak
} 
salah satu upaya kesehatan anak remaja yang ditetapkan melalui Instruksi Presiden yaitu Pelayanan Kesehatan Peduli Remaja (PKPR) di Puskesmas betujuan untuk meningkatkan pengetahuan dan keterampilan remaja tentang kesehatan reproduksi dan perilaku hidup sehat serta memberikan pelayanan yang berkuaitas kepada remaja. Menurut Supariasa, 2016 selain asupan protein, faktor lain yang dapat menyebabkan tejadinya anemia adalah status gizi. Seseorang dengan status gizi kurang akan mudah terkena infeksi. Prevalensi anemia semakin meningkat dengan semakin memburuknya status gizi seseorang (Dewi, 2018).

Pengetahuan merupakan hasil dari tahu, yang terjadi setelah orang melakukan penginderaan terhadap objek tertentu. Sebagian besar pengetahuan diperoleh melalui mata dan telinga. Pengetahuan merupakan pedoman dalam membentuk tindakan seseorang (overt behavior). Berdasarkan pengalaman dan penelitian, diperoleh bahwa perilaku yang didasari oleh pengetahuan lebih langgeng dari pada perilaku yang tidak didasari pengetahuan (Maulana, 2009).

Pengetahuan merupakan faktor yang penting namun tidak memadai dalam perubahan perilaku kesehatan. Pengetahuan seseorang mengenai kesehatan yang diharapkan mungkin tidak akan terjadi kecuali seseorang mempunyai motivasi untuk bertindak atas dasar pengetahuan yang dimilkinya (Green, 1980; Notoatmodjo, 2010).

Masalah kekurangan dan kelebihan gizi pada orang dewasa (usia 18 tahun keatas) merupakan masalah penting, karena selain mempunyai resiko penyakit-penyakit tertentu, juga dapat mempengaruhi produktifitas kerja. Oleh karena itu, pemantauan keadaan tersebut perlu dilakukan secara berkesinambungan. Orang-orang yang berada di bawah ukuran berat normal mempunyai risiko terhadap penyakit infeksi, sementara yang berada diatas ukuran normal mempunyai risiko tinggi terhadap penyakit degenerative (Supariasa, 2002). Akhirnya diambil kesimpulan ambang batas IMT untuk Indonesia adalah seperti dibawah ini (Supariasa, 2002).

Tabel 1 Kategori Ambang Batas Indeks Massa Tubuh Untuk Indonesia

\begin{tabular}{lll}
\hline & Kategori & IMT \\
\hline \multirow{2}{*}{ Kurus } & Kekurangan BB tingkat berat & $<17,0$ \\
\multirow{2}{*}{ Normal } & Kekurangan BB tingkat ringan & $17,0-18,5$ \\
\multirow{2}{*}{ Gemuk } & & $>18,5-25,0$ \\
& Kelebihan BB tingkat berat & $>25,0-27,0$ \\
\hline
\end{tabular}

Status gizi remaja merupakan kondisi tubuh yang muncul diakibatkan adanya keseimbangan antara konsumsi dan pengeluaran zat gizi. Masalah gizi yang terjadi pada remaja merupakan kelanjutan dari masalah gizi pada usia anak, yaitu anemia kekurangan besi serta kekurangan dan kelebihan berat badan (Arisman, 2009). 
Menurut Irianto, 2014 mengatakan Hemoglobin adalah metaloprotein (protein yang mengandung zat besi) didalam sel darah merah yang berfungsi sebagai pengankut oksigen dari paru-paru ke seluruh tubuh.
Menurut Setiawan, 2010 mengatakan bahwa faktor yang menyebabkan turunnya kadar hemoglobin adalah sebagai berikut: Perdarahan, Cacat pada sel darah merah (SDM), Kekurangan zat besi.

Tabel 2 Batas Normal Hemoglobin pada berbagai kelompok

\begin{tabular}{lc}
\hline \multicolumn{1}{c}{ Kelompok } & Hemoglobin $(\mathrm{g} / \mathrm{dl})$ \\
\hline Anak umur 6 bulan -5 tahun & 11,0 \\
Anak umur 5 tahun -11 tahun & 11,5 \\
Anak umur 12 tahun -14 tahun & 12,0 \\
Laki-laki dewasa & 13,0 \\
Wanita dewasa tidak hamil & 12,0 \\
Wanita hamil & 11,0 \\
\hline
\end{tabular}

Menurut Gillespie (1997) yang dikutip oleh WHO (2005)bahwa intervensi pada remaja putri mempunyai manfaat yang terkait reproduksi: 1) meningkatkan berat badan sebelum hamil dan cadangan gizi, yang berkontribusi terhadap perbaikan outcome kehamilan dan laktasi; 2) memperbaiki status besi dengan berkurangnya risiko anemia pada masa hamil, berat badan lahir rendal (BBLR), kesakitan dan kematian ibu, meningkatkan produktivitas kerja dan pertumbuhan linier, 3) memperbaiki status folat, serta berkurangnya anemia megaloblastik pada masa kehamilan (Pattimah, 2017).

Kebutuhan zat gizi usia remaja menurut Susilowati (2016) terdiri dari: Energi, Protein, Lemak dan karbohidrat, Vitamin, Mineral, kebutuhan kalsium pada masa remaja relative tinggi karena akselerasi muscular, skeletal atau kerangka dan perkembangan endokrin dibandingkan masa kanak-kanak.

Berdasarkan hasil penelitian dari Dinda Putri tentang Hubungan Pengetahuan dan Status Gizi dengan Kadar HemoglobinPada
Remaja Putri di SMPN 01 Rasau Jaya Kabupaten Kubu Raya Tahun 2016 menunjukkan bahwa jenis penelitian yang digunakan adalah deskriptif korelasi dengan racangan study cross sectional. Pengambilan sampel dilakukan menggunakan teknik Quota Random Sampling dengan jumlah sampel 30 orang.

Pengumpulan data dilakukan dengan pengambilan data sekunder dan data primer yang meliputi wawancara dengan menggunakan kuesioner dan hasil pemeriksaan. Analisis data dilakukan dengan menggunakan uji chi-square. Hasil penelitian menunjukan bahwa pengetahun tidak memiliki hubungan yang bermakna dengan kadar hemoglobin memiliki ( $\mathrm{p}=0117<0,05)$, begitu juga degitu juga dengan pengetahuan memiliki hubungan yang bermakna dengan status $\mathrm{Hb} \quad(\mathrm{p}=0,117<0,05)$. Namun ada hubungan yang bermakna antara status gizi dengan kadar $\mathrm{Hb}(\mathrm{p}=0,001>0,05)$.

Berdasarkan Hasil Penelitian Dewi Pertiwi Dyah Kuyusdaryati tentang Hubungan 
Asupan Gizi dan Status Gizi dengan Kadar Hemoglobin pada Remaja Putri Anemia Tahun 2018 menunjukan bahwa desain penelitian menggunakan observasional analitik dengan pendekatan cross sectional. Subyek penelitianmerupakan remaja anemia sebanyak 20 subyek yang diambil secaraoncecutve sampling. Kadar hemoglobin diperoleh dari pemeriksaan darahsedangkan asupan protein diperoleh dari wawancara Food Recall24 jam. Status gizi diperoleh dari data Indeks Massa Tubuh. Data dianalisismenggunakan uji Rank Spearman. Hasil penelitian menunjukkan tidak adahubungan asupan protein dengan kadar hemoglobin $(\mathrm{p}=0,515)$.

Berdasarkan hasil asupan subyek didapatkan hasil sebagian besar subyek memiliki tingkat kecukupan protein yang normal. Hasil uji statistik menunjukkan tidak adahubungan status gizi dengan kadar hemoglobin $(\mathrm{p}=0,601)$. Sebagian besar subyek masuk dalam kategori gizi baik. Kesimpulan penelitian ini adalah tidakada hubungan asupan protein dan status gizi dengan kadar hemoglobin pada remaja putri anemia.

Jumlah mahasiswi di Akademi Kebidanan Panca Bhakti pada tahun akademik 2018/2019 merupakan remaja putri dengan jumlah total 250 orang dari angkatan 13 terdiri dari 107 orang, angkatan 14 terdiri dari 71 orang dan angkatan 15 terdiri dari 72 orang. Sedangkan jumlah mahasiswi yang tinggal diasrama dengan jumlah total 51 orang dari angkatan 13 terdiri dari 11 orang, angkatan 14 terdiri dari 13 orang dan angkatan 15 terdiri dari 28 orang.

Akademi Kebidanan Panca Bhakti Kabupaten Kubu Raya Pontianak memiliki fasilitas tempat tinggal sementara yaitu asrama. Berdasarkan hasil studi pendahuluan yang dilakukan peneliti pada bulan Maret Tahun 2019 pada 10 orang mahasiswi Akademi Kebidanan Panca Bhakti Pontianak yang tidak tinggal diasrama dengan hasil 3 orang memiliki pengetahuan tentang gizi remaja yang kurang, 1 orang yang memiliki IMT (Indeks Massa Tubuh) gemuk mengalami anemia, serta 3 orang yang memiliki IMT (Indeks Massa Tubuh) kategori kurus tidak mengalami anemia.

\section{Metodologi}

Penelitian ini menggunakan desain Observasional analitik dengan pendekatan cross sectional. Penelitian ini ingin mengetahui hubungan Antara Pengetahuan dan Indeks Massa Tubuh dengan Kadar Hemoglobin Remaja Putri yang dialkasanakan pada bulan Februari sampai dengan Juni 2019. Populasi dalam penelitian ini adalah semua remaja putri di Asrama Akademi Kebidanan Panca Bhakti Kabupaten Kubu Raya Pontianak yang berjumlah 51 orang. Pengumpulan data yang dilakukan dalam penelitian ini yaitu dengan menggunakan kuisioner dan menggunakan lembar chek list, kemudian diolah dan dianalisis menggunakan analisis univariat dan bivariate menggunakan uji chi square. 


\section{Hasil dan Pembahasan}

Tabel 3. Distribusi Frekuensi Responden Menurut Pengetahuan, Indeks Massa Tubuh dan Kadar Hemoglobin Remaja Putri di Asrama Akademi Kebidanan Panca Bhakti Kabupaten Kubu Raya Pontianak Tahun 2019

\begin{tabular}{|c|c|c|}
\hline Variabel & Frekuensi & Persentase (\%) \\
\hline \multicolumn{3}{|l|}{ Pengetahuan: } \\
\hline Kurang & 22 & 43 \\
\hline Baik & 29 & 57 \\
\hline \multicolumn{3}{|l|}{ Indeks Massa Tubuh: } \\
\hline Tidak Normal & 23 & 45 \\
\hline Normal & 28 & 55 \\
\hline \multicolumn{3}{|l|}{ Kadar Hemoglobin: } \\
\hline Anemia & 18 & 35 \\
\hline Tidak Anemia & 33 & 65 \\
\hline
\end{tabular}

Berdasarkan tabel di atas dapat disimpulkan bahwa sebagian dari responden yaitu 29 responden $(57 \%)$ memiliki pengetahuan yang baik tentang kebutuhan gizi pada remaja. Sebagian dari reponden yaitu 28 orang (55\%) memiliki status gizi yang ditunjukkan dengan Indeks Massa Tubuh (IMT) normal. Sebagian besar dari reponden yaitu 33 orang $(65 \%)$ memiliki kadar hemoglobin $(\geq 12,0 \mathrm{~g} / \mathrm{dl})$ atau tidak anemia.

Tabel 4. Analisis Bivariat Hubungan Antara Pengetahuan tentang Kebutuhan gizi dan Indeks Massa Tubuh dengan Kadar Hemoglobin pada Remaja Putri di Asrama Akademi Kebidanan Panca Bhakti Kabupaten Kubu Raya Pontianak Tahun 2019

\begin{tabular}{|c|c|c|c|c|c|c|}
\hline \multirow{3}{*}{ Variabel } & \multicolumn{4}{|c|}{ Kadar Hemoglobin } & \multirow{3}{*}{$X^{2}$} & \multirow{3}{*}{$\mathrm{X}$ tab } \\
\hline & \multicolumn{2}{|c|}{ Anemia } & \multicolumn{2}{|c|}{ Tidak Anemia } & & \\
\hline & $\mathrm{n}$ & $\%$ & $\mathrm{n}$ & $\%$ & & \\
\hline \multicolumn{7}{|l|}{ Pengetahuan } \\
\hline Kurang & 4 & 14 & 25 & 86 & & \\
\hline Baik & 14 & 64 & 8 & 36 & 13,63 & 3,841 \\
\hline \multicolumn{7}{|l|}{ Indeks Massa Tubuh } \\
\hline Tidak Normal & 13 & 57 & 10 & 43 & & \\
\hline Normal & 5 & 18 & 23 & 82 & 8,25 & \\
\hline
\end{tabular}

Hasil analisis hubungan antara
pengetahuan dengan kadar hemoglobin
diperoleh bahwa hampir seluruh responden
yaitu $25(86 \%)$ yang memiliki pengetahuan
kurang tidak mengalami anemia, sedangkan sebagian kecil dari responden yaitu 8 (36\%) yang memiliki pengetahuan baik tidak mengalami anemia. Hasil uji statistik diperoleh nilai X hitung $(13,63)$ lebih besar dari $\mathrm{X}$ tabel $(3,841)$ maka disimpulkan bahwa ada hubungan antara pengetahuan tentang kebutuhan gizi remaja dengan kadar hemoglobin pada remaja putri di Asrama Akademi Kebidanan Panca Bhakti Pontianak Kabupaten Kubu Raya pada tahun 2019.

Hasil analisis hubungan antara Indeks Massa Tubuh (IMT) dengan kadar hemoglobin diperoleh bahwa sebagian dari responden yaitu $10(43 \%)$ memiliki Indeks Massa Tubuh dengan kategori tidak normal 
tidak mengalami anemia, sedangkan hampir seluruh responden yaitu 23 (82 \%) yang memiliki Indeks Massa Tubuh normal tidak mengalami anemia. Hasil uji statistik diperoleh nilai $X$ hitung $(8,25)$ lebih besar dari $\mathrm{X}$ tabel $(3,841)$ maka disimpulkan bahwa ada hubungan antara Indeks Massa Tubuh (IMT) dengan kadar hemoglobin pada remaja putri di Asrama Akademi Kebidanan Panca Bhakti Pontianak Kabupaten Kubu Raya pada tahun 2019.

Berdasarkan hasil penelitian terhadap remaja putri di Asrama Akademi Kebidanan Panca Bhakti Pontianak Kabupaten Kubu Raya Tahun 2019 didapatkan bahwa pengetahuan tentang kebutuhan gizi remaja sebagian dari reponden yaitu $22(43 \%)$ dan 29 (57 \%) memiliki pengetahuan kurang dan baik. Pengetahuan merupakan hasil dari tahu, yang terjadi setelah orang melakukan penginderaan terhadap objek tertentu. Sebagian besar pengetahuan diperoleh melalui mata dan telinga. Pengetahuan merupakan pedoman dalam membentuk tindakan seseorang (overt behavior). Berdasarkan pengalaman dan penelitian, diperoleh bahwa perilaku yang didasari oleh pengetahuan lebih langgeng dari pada perilaku yang tidak didasari pengetahuan (Maulana, 2009).

Remaja termasuk salah satu kelompok rentan gizi yang disebabkan oleh: (1) percepatan pertumbuhan dan perkembangan tubuh memerlukan zat gizi yang lebih banyak, (2) perubahan gaya hidup dan kebiasaan makan yang menuntut penyesuaian asupan gizi, (3) kehamilan, aktif dalam kegiatan olahraga, menderita penyakit, yang meningkatkan kebutuhan zat gizi. Masalah nutrisi utama pada remaja adalah defisiensi mikronutrien, khususnya anemia defisiensi zat besi, serta masalah malnutrisi, baik gizi kurang dan perawakan pendek maupun gizi lebih sampai obesitas dengan komorbiditasnya yang keduanya seringkali berkaitan dengan perilaku makan salah. (Patimah, 2017).

Berdasarkan hasil penelitian terhadap remaja putri di Asrama Akademi Kebidanan Panca Bhakti Pontianak Kabupaten Kubu Raya Tahun 2019 didapatkan bahwa Indeks Massa Tubuh (IMT) remaja putri sebagian dari reponden yaitu $23(4 \%)$ dan $28(55 \%)$ memiliki Indeks Massa Tubuh (IMT) tidak normal dan normal. Menurut Hasdianah, 2014 mengatakan Indeks Massa Tubuh (IMT) merupakan alat yang sederhana untuk memantau status gizi orang dewasa, khususnya yang berkaitan dengan kekurangan dan kelebihan berat badan.

Masalah kekurangan dan kelebihan gizi pada orang dewasa (usia 18 tahun keatas) merupakan masalah penting, karena selain mempunyai resiko penyakit-penyakit tertentu, juga dapat mempengaruhi produktifitas kerja. Oleh karena itu, pemantauan keadaan tersebut perlu dilakukan secara berkesinambungan. Salah satu cara adalah dengan mempertahankan berat badan yang ideal atau normal (Supariasa, 2002).

Berat badan yang berada dibawah batas minimum dinyatakan sebagai underweight 
atau "kekurusan", dan berat badan yang berada diatas batas maksimum dinyatakan sebagai "over weiht" atau kegemukan. Orangorang yang berada di bawah ukuran berat normal mempunyai risiko terhadap penyakit infeksi, sementara yang berada diatas ukuran normal mempunyai risiko tinggi terhadap penyakit degenerative (Supariasa, 2002).

Secara umum, status gizi dipengaruhi oleh konsumsi zat gizi dari makanan dan penyakit infeksi yang mengganggu proses metabolisme, absorpsi, dan utilisasi zat gizi oleh tubuh. UNICEF (1998) mengembangkan sebuah kerangka yang memperkenalkan penyebab utama dan penyebab dasar dari kekurangan gizi, termasuk faktor lingkungan, ekonomi, dan konteks sosial politik dengan kemiskinan yang mempunyai peran sentral. Kekurangan gizi meliputi stunting, wasting, dan kekurangan beberapa vitamin dan mineral (gizimikro) sebagai satu bentuk dari beberapa kondisi yang dikenal dengan malnutrisi, dengan obesitas atau kelebihan konsumsi dari zat-zat gizi sebagai bentuk lain dari malnutrisi (Arisman,2009).

Berdasarkan hasil penelitian terhadap remaja putri di Asrama Akademi Kebidanan Panca Bhakti Pontianak Kabupaten Kubu Raya Tahun 2019 didapatkan bahwa kadar Hemoglobin remaja putri sebagian kecil dari reponden yaitu 18 (35\%) mengalami anemia dan sebagian besar dari reponden $33(65 \%)$ tidak mengalami anemia.

Menurut Saputra, 2013 mengatakan bahwa Hemoglobin merupakan protein konyugasi dengan berat molekul 64.400 .
Menurut Irianto, 2014 mengatakan Hemoglobin adalah metaloprotein (protein yang mengandung zat besi) didalam sel darah merah yang berfungsi sebagai pengankut oksigen dari paru-paru ke seluruh tubuh. Menurut Widjajakusumah, 2003 mengatakan pigmen merah yang membawa oksigen dalam sel darah merah adalah hemoglobin.

Menurut Setiawan, 2010 mengatakan bahwa faktor yang menyebabkan turunnya kadar hemoglobin adalah Kekurangan zat besi, Penyebab langsung dari turunnya kadar hemoglobin adalah ketidak cukupan asupan $\mathrm{Fe}$ dan infeksi penyakit seperti cacing tambang. Seseorang yang asupan zat besinya cukup tetapi jika sering terinfeksi cacing tambang dapat menderita anemia. Demikian juga jika seseorang yang asupan zat besi rendah maka daya tahan tubuhnya berkurang sehingga mudah terserang penyakit dan akhirnya akan mengalami penurunan kadar hemoglobin.

Penyebab tidak langsung adalah rendahnya kandungan $\mathrm{Fe}$ dan tingginya zat penghambat absobsi $\mathrm{Fe}$ serta sanitasi lingkungan dan pelayanan kesehatan yang kurang memadai. Ketiga faktor tersebut berkaitan dengan dan bersumber pada akar permasalahan yaitu rendahnya pemberdayaan masyarakat, kurang memiliki pengetahuan tentang anemia defisiensi besi dan makanan yang mengandung $\mathrm{Fe}$ relatif tinggi. Rendahnya pemberdayaan masyarakat ini disebabkan kondisi politik, sosial, ekonomi yang kurang mampu memanfaatkan sumberdaya yang ada. Penyebab tidak 
langsung lainya yang berhubungan dengan ketidakcukupan Fe adalah status pekerjaan.

Hasil analisis hubungan antara pengetahuan dengan kadar hemoglobin diperoleh bahwa hampir seluruh responden yaitu $25(86 \%)$ yang memiliki pengetahuan kurang tidak mengalami anemia, sedangkan sebagian kecil dari responden yaitu 8 (36\%) yang memiliki pengetahuan baik tidak mengalami anemia. Hasil uji statistik diperoleh nilai X hitung $(13,63)$ lebih besar dari X tabel $(3,841)$ maka disimpulkan bahwa ada hubungan antara pengetahuan tentang kebutuhan gizi remaja dengan kadar hemoglobin pada remaja putri di Asrama Akademi Kebidanan Panca Bhakti Pontianak Kabupaten Kubu Raya pada tahun 2019.

Penelitian ini juga sejalan dengan penelitian yang dilakukan oleh Yunda dan Nindya pada tahun 2017 dengan judul hubungan pengetahuan tentang gizi seimbang dengan status gizi pada remaja remaja putri kelas 11 akutansi 2 di SMK PGRI 2 Kota Kediri menunjukkan ada hubungan antara pengetahuan dengan status gizi pada remaja putri yang dilakukan pada 50 orang responden.

Defisiensi zat besi adalah penyebab anemia yang sering terjadi pada wanita usia subur tertentu (51\%) diseluruh dunia. Wanita memiliki sekitar 2,3 g zat besi total didalam tubuh yang sebagian besarnya (80\%) ditemukan dalam Massa sel darah merahsebagai Hemoglobin (Hb). Anemia menyebabkan penurunan kapasitas darah untuk membawa oksigen. Pada pemeriksaan mikroskopik, sel darah merah terlihat mikrostik dan hipokromik. Anemia defisiensi zat besi terjadi akibat peningkatan kebutuhan zat besi atau ketidakadekuatan absorpsi zat besi. Berdasarkan data prevalensi anemia remaja putri yang bervariasi diberbagai negara menunjukan bahwa derajat anemia menurut WHO untuk dinyatakan sebagai masalah kesehatan masyarakat juga bervariasi dari tingkat ringga hingga berat. WHO (2008) menyatakan bahwa jika prevalensi kejadian anemia di masyarakat sebesar $\geq 5 \%$ dinyatakan sebagai masalah kesehatan masyarakat. Berdasarkan derajat masalahnya dinyatakan tingkat ringan apabila prevalensi anemia di masyarakat sebanyak 5-19\%, derajat sedang jika angka prevalensi anemia berada pada rentag 20-39,9\%, sedangkan prevalensi $\geq 400 \%$ dianggap masalah kesehatan masyarakat yang tergolong berat (Patimah, 2017).

Hasil analisis hubungan antara Indeks Massa Tubuh (IMT) dengan kadar hemoglobin diperoleh bahwa sebagian dari responden yaitu 10 (43\%) memiliki Indeks Massa Tubuh dengan kategori tidak normal tidak mengalami anemia, sedangkan hampir seluruh responden yaitu 23 (82 \%) yang memiliki Indeks Massa Tubuh normal tidak mengalami anemia. Hasil uji statistik diperoleh nilai $\mathrm{X}$ hitung $(8,25)$ lebih besar dari $\mathrm{X}$ tabel $(3,841)$ maka disimpulkan bahwa ada hubungan antara Indeks Massa Tubuh (IMT) dengan kadar hemoglobin pada remaja putri di Asrama Akademi Kebidanan Panca Bhakti 
Pontianak Kabupaten Kubu Raya pada tahun 2019.

Menurut Thompson dalam penelitian Arumsari, 2008 mengatakan status gizi mempunyai korelasi positif dengan konsentrasi hemoglobin, artinya semakin buruk status gizi seseorang maka semakin rendah kadar hemoglobin orang tersebut. Menurut Wibowo dalam penelitian Karian Janeta, 2016 mengatakan bahwa kebiasaan yang sering dilakukan oleh kebanyakan remaja baik putra maupun putri mengkonsumsi makanan yang kurang bergizi dan makan tidak teratur, sedangkan banyak dari mereka melakukan aktivitas belajar dengan kegiatan ekstrakurikuler yang padat sehingga mengalami gangguan pencernaan, akibatnya proses penyerapan dalam tubuh terganggu sehingga menyebabkan kekurangan nutrisi dan juga zat besi yang mempengaruhi ukuran bentuk tubuh dan status gizi, serta kadar hemoglobin remaja (Krina, 2016).

Anemia merupakan kondisi dimana tubuh memiliki jumlah sel darah merah yang sangat sedikit. Sel darah merah mengandung hemoglobin yang berfungsi untuk membawa oksigen ke jaringan tubuh. Asupan zat gizi seperti protein yang kurang akan memperberat terjadinya anemia serta berdampak pada terjadinya gizi kurang. Secara tidak langsung status gizi juga akan berpengaruh terhadap terjadinya anemia (Dewi, 2018).

Penelitian sebelumnya telah menunjukkan kekurangan dan kelebihan gizi merupakan salah satu faktor resiko anemia.
Underweight merupakan indikasi rendahnya asupan mikronutrien yang berhubungan dengan metabolisme besi. Overweight atau obesitas juga meningkatkan resiko anemia karena terjadinya penimbunan lemak. Penimbunan lemak pada orang overweight atau obesitas menimbulkan reaksi inflamasi dan peningkatan sitokin (IL-6) sehingga menstimulasi peningkatan hepsidin dan menurunkan penyerapan zat besi di usus. Selain itu, timbunan lemak pada hati dapat memicu pembentukan peroksida lipid yang merusak membran sel darah merah dan mengganggu sintesis hemoglobin (Putri, 2019).

Underweight berhubungan dengan defisiensi makronutrien dan mikronutrien termasuk zat besi. Pada wanita dengan Indeks Massa Tubuh (IMT) kurang, asupan makronutrien dan mikronutriennya tidak adekuat. Makronutrien utama yang berperan dalam metabolisme besi adalah protein. Defisiensi protein akan meyebabkan transportasi besi terganggu dan meningkatkan resiko infeksi. Mikronutrien yang berperan dalam penyerapan dan metabolisme besi diantaranya protein, zat besi, asam folat, vitamin $\mathrm{C}$, vitamin $\mathrm{B} 12$, vitamin $\mathrm{A}$, zinc dan tembaga. Kekurangan makronutrien dan mikronutrien ini menyebabkan terganggunya penyerapan dan metabolism besi karena tidak cukupnya jumlah besi yang dibutuhkan, sehingga akan mengganggu sintesis hemoglobin (Putri, 2019).

Selain itu, overweight atau obesitas juga berkaitan dengan anemia. Overweight 
atau obesitas berkaitan dengan anemia karena penimbunan lemak di jaringan adiposa. Penimbunan lemak ini yang dapat menurunkan penyerapan zat besi. Jaringan lemak pada obesitas menyebabkan terjadinya inflamasi kronik yang mana berhubungan dengan ekspresi sitokin proinflamatory, diantaranya Interleukin-6 (IL-6) dan Tumor Necrosis Factor- $\alpha$ (TNF- $\alpha)$ (Putri, 2019).

\section{Kesimpulan}

Berdasarkan hasil penelitian yang telah dilakukan, maka dapat disimpulkan bahwa ada hubungan antara pengetahuan tentang kebutuhan gizi dan Indeks Massa Tubuh (IMT) dengan kadar hemoglobin pada remaja putri di Asrama Akademi Kebidanan Panca Bhakti Pontianak Kabupaten Kubu Raya. Saran yang dapat peneliti sampaikan adalah penelitian ini dapat digunakan sebagai informasi dan referensi dalam menunjang proses belajar mengajar di Akademi Kebidanan Panca Bhakti Pontianak.

\section{Daftar Pustaka}

Arikunto, Suharsimi. 2010. Prosedur Penelitian Suatu Pendekatan Praktek. Jakarta: PT Rineka Cipta.

Arisman, M. B. 2004. Gizi Dalam Daur Kehidupan. Jakarta: Buku Kedokteran EGC.

Ganong, William. F. 2003. Buku Ajar Fisiologi Kedokteran E/20. Jakarta: EGC

Hasdianah. 2014. Gizi Pemanfaatan Gizi, Diet dan Obesitas. Yogyakarta: Nuha Medika.
Hidayat, Aziz Alimun. 2007. Metode Penelitian Kebidanan Teknik Analisis Data. Jakarta: Salemba Medika.

Irianto, Djoko Pekik. 2017. Pedoman Gizi Lengkap, Keluarga dan Olahragawan.Yogyakarta: CV. Andi Offset.

Irianto, Koes. 2014. Gizi Seimabang Dalam Kesehatan Reproduksi (Balancer Nutrition In Reproductive Health). Bandung: CV. Alvabeta

Notoadmodjo, Soekidjo. 2010. Metodelogi Penelitian Kesehatan. Jakarta: PT. Rineka Cipta.

Notoadmodjo, Soekidjo. 2014. Ilmu Perilaku Kesehatan. Jakarta: PT. Rineka Cipta.

Patimah, Sitti. 2017, Gizi Remaja Putri Plus 1000 Hari Pertama Kehidupan, Bandung: Refika Aditama.

Riskesdas. 2018. Hasil Utama Riskesdas Tentang Prevalensi Diabetes Mellitus di Indonesia 2018. https://doi.org/1 Desember2013 Diakses tanggal 28 Maret 2019 Pukul: 12.05.

Saputra, Lyndon. 2013. Buku Ajar Patofisiologi. Tangerang: Binapura Aksara Publisher.

Setiawan, Ari dan Saryono. 2011. Metodelogi Penelitian Kebidanan D III, D IV, S1 dan S2. Yogyakarta: Nuha Medika.

Supariasa, Dewa Nyoman. 2002. Penilaian Status Gizi. Jakarta: Buku Kedokteran EGC.

Sukarno, J, Marunduh, R, dan Pengemanan, D. H. C. 2016. Hubungan Indeks Massa Tubuh dengan Kadar

Susilowati, SKM, MKM dan Kuspriyanto, S.Si. Apt. 2016. Gizi Dalam Daur Kehidupan. Bandung: PT. Refika Aditama.

Hemoglobin Pada Remaja di Kecamatan Bolangitang Barat Kabupaten Bolaang Mongondow Utara. Jurnal Kedokteran 
Klinik, 1(1), 2. Diakses pada tanggal 26 Maret 2019 Pukul 12.05.

Susila dan Suyanto. 2014. Metodelogi Penelitian Kesehatan dan Kedokteran. Yogyakarta: Bursa Ilmu.

Sugiyono. 2011. Statistik Untuk Penelitian. Bandung: CV. Alvabeta.

Yunda Dwi Jayanti dan Nidya Elsa Novananda, 2017, Hubungan Pengetahuan Tentang Gizi Seimbang Dengan Status Gizi Pada Remaja Putri Kelas XI Akuntansi 2 (Di Smk Pgri 2 Kota Kediri) https://akbiddharmahusada-kediri.ejournal.id/JKDH/article/view/38

Diakses tanggal 28 Maret 2019 Pukul: 12.05 . 